\title{
Şirketler Hukuku Derslerı ile İlgili bir Anket
}

Dr. T. ANSAY

Ankara Hukuk Fakültesi 3. smif derslerinden olan Ticaret Hukukunun Şirketler Hukuku kısmını 1967-68 ders yll içinde okutmuş bulunuyorum. Derslerden ve bu ders için hazırlamış olduğum Anonim Şirketler Hukuku kitabından ögrencilerin yararlanma derecesini ölçebilmek ve aksaklıkları giderebihnek amacı ile yıl sonunda bir anket düzenledim. Bu çeşit denerneler Fakültemizde daha önceki yıllarda da yapılmıştır *. Fakat anketlerin metinleri ve

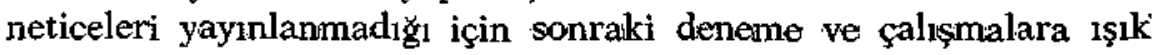
tutamamıştır. Bu sebepten ankette sorduğum soruları ve bazı sonuçlari kısaca yayınlamakta fayda gördüim.

\section{Anketin metni :}

«Lïtfen aşağıdaki soruları cevaplandırınız : Bütün sorulara cevap vermeniz zorunlu değildir. Cevapları, soruların etrafina bir daire çizmek suretiyle işaretleyiniz.

Dikkat : Isim yazılmayacaktır.

1. Şirketler hukuku ilgi çekici ilgi çekici değil fikrim yok

2. Anonim şirketler kitabın okumak ve anlamakta

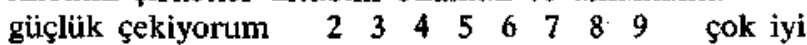

3. Anonim şirketler kitabındaki mahkeme kararları $\begin{array}{lllllllllll}\text { faydasız } & 2 & 3 & 4 & 5 & 6 & 7 & 8 & 9 & \text { çok faydalı }\end{array}$

4. Şirketler hukukunda mecburi olan kitaplar dışında başka kitap ve makaleler

$$
\text { okudum okumadım }
$$

5. Derslerde not tutarım sadece esasları yazarım hiç yazmam

(*) Almanya'nın yeni kurulan Bochem Universitesi Hukuk Fakültesinde de ayn tarihlerde derslerle ilgili bir anketin yapilms oldugunu tespit ettim. Bu anket için bak. Bochumer Fragebogen zur «Vorlesungskritik», Juristische Schulung 196 (1968). 
6. Konularn derste

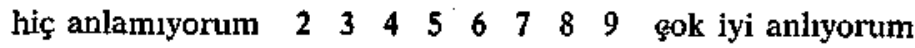

7. Şirketler hukuku pratik kurları $\begin{array}{lllllllllll}\text { faydasız } & 2 & 3 & 4 & 5 & 6 & 7 & 8 & 9 & \text { çok faydalı }\end{array}$

8. Şirketler hukuku derslerinde tartışmalara yeteri kadar yer verilmiyor yer veriliyor

9. Sene içinde imtihan yapılmasını istiyor musunuz? 1 defa 2 defa daha çok

10. Şirketler hukuku dersleri hakkında düșündiiğünüzz diğer hususları kısaca yazınız (Cevaplandırılması zorunlu değildir)."

Anonim Şirketler Hukuku kitabımda bugüne kadar memleketimizde alıșılmamış olan, mahkeme kararları ile anlatma metoduna küçïk ölçüde yer verilmiştir. Kitapta sistematik izahatlardan sonra Türk Yargitayı ile Isviçre Federal Mahkemesinin kararlarının en önemlilerinden bir kısmı aynen yayınlanmıștır. Bu mahkeme kararlarının faydası hakkında sorulan soruyu 206 ögrenici cevaplandırmıştır. Bunlardan 41'i kararları faydasız, 31'i ise çok faydalı bulnuuşlardır. Derecelendirme șöyledir :

$$
\begin{array}{crrrrrrrrc}
\text { faydasiz } & 2 & 3 & 4 & 5 & 6 & 7 & 8 & 9 & \text { cok faydal } \\
41 & 11 & 8 & 12 & 21 & 20 & 18 & 22 & 22 & 31
\end{array}
$$

Ayrica 10. soruya verilen cevaplar arasında da 20 öğrenci kararlan anlamakta güçlük çektiklerini bir kere daha belirtmişlerdir.

Dördüncü soruyu 197 öğrenci cevaplandırmıștır. Bunlardan $169 \mathrm{u}$ ana ders kitabı dıșında başka bir kitap veya makale okumadiklarını ifade etmișlerdir.

198 ögrencinin 81'i yll içinde 2 yazılı sınav yapılmasma taraftardırlar. 24 ögrenci 1 sınav, 91 öğrenci ise 2 den fazla sınav yaplmasını istemektedirler. Sadece 2 öğrenci yıl iç̧ sınavlarının aley. hindedir. 